\title{
Fish community of the river Tiber basin (Umbria-Italy): temporal changes and possible threats to native biodiversity
}

\author{
A. Carosi $i^{(1), \star}$, L. Ghetti ${ }^{(2)}$, A. Forconi $i^{(1)}$, M. Lorenzoni ${ }^{(1)}$ \\ Received April 10, 2015
}

Revised August 2, 2015

Accepted August 3, 2015

Key-words: introduction, exotic species, fish community, river Tiber, longitudinal gradient

\section{ABSTRACT}

The introduction of exotic fish species in the river Tiber basin has probably caused a serious alteration of original faunal composition. The purpose of this research was to assess the changes occurred over time in the state of the fish communities with particular reference to the reduction of local communities of endemic species. The study area comprised 68 watercourses of the Umbrian portion of the River Tiber basin; the analyses were carried out using the data of the Regional Fish Map of 1st and 2nd level and the 1st update, respectively collected during the periods between the 1990-1996, 2000-2006 and 2007-2014, in 125 sampling stations. The results show a progressive alteration of the fish communities' structure, as confirmed by the appearance in recent times of new alien species. A total of 40 species was found, only 14 native. The qualitative change of the fish communities appear to be closely related to the longitudinal gradient of the river. The results shows that particularly in the downstream reaches, the combined action of pollution and introduction of exotic species resulted in a gradual decrease in the indigenous component of fish communities. The information collected are the indispensable premise for taking the necessary strategies for conservation of endangered species.

\section{RÉSUMÉ}

La communauté piscicole du bassin du Tibre (Ombrie-Italie) : changements temporels et menaces possibles à la biodiversité originale

Mots-clés : introduction, espèces exotiques, communautés de poissons, rivière Tibre,
L'introduction d'espèces exotiques de poissons dans le bassin du fleuve Tibre a probablement provoqué une grave altération de la composition de la faune originale. Le but de cette recherche était d'évaluer les changements survenus au fil du temps dans l'état des communautés de poissons avec une référence particulière à la réduction des communautés locales d'espèces endémiques. La zone d'étude comprend 68 cours d'eau de la partie de l'Ombrie du bassin du fleuve Tibre; les analyses ont été effectuées en utilisant les données de la carte piscicole régionale de $1^{\mathrm{er}}$ et $2^{\mathrm{e}}$ niveau et de la $1^{\mathrm{re}}$ mise à jour, respectivement recueillies pendant les périodes entre le 1990-1996, 2000-2006 et 2007-2014, dans 125 stations

(1) Dipartimento di Chimica, Biologia e Biotecnologie dell'Università degli Studi di Perugia, Via Elce di Sotto, 06100 Perugia, Italy

(2) Servizio Caccia e Pesca Regione dell'Umbria, Perugia, Italy

* Corresponding author: acarosi@libero.it 
pente longitudinale d'échantillonnage. Les résultats montrent une altération progressive de la structure des communautés de poissons, confirmée par l'apparition ces derniers temps de nouvelles espèces exotiques. Un total de 40 espèces a été trouvé, seulement 14 natives. Le changement qualitatif des communautés de poissons semble être étroitement lié à la pente longitudinale de la rivière. Les résultats montrent que, particulièrement dans les tronçons situés en aval, l'action combinée de la pollution et de l'introduction d'espèces exotiques a entraîné une diminution progressive de la composante autochtone des communautés de poissons. Les informations recueillies sont la prémisse indispensable pour adopter les stratégies nécessaires à la conservation des espèces menacées.

\section{INTRODUCTION}

Italy is one of the most important european areas in regard to fish biodiversity due to the presence of a high number of endemic species (Smith and Darwall, 2006). Endemic species are particularly important for the conservation of biodiversity, as being distributed on a territory generally very limited, they are potentially exposed to greater risks of extinction. These risks are particularly high for the Umbria region because the number of endemic species with particularly restricted range is higher than elsewhere (Kottelat and Freyhof, 2007). In Italy there are two ichtyogeographic districts that can be identified on the basis of the dispersion processes that have characterized the fish fauna in the course of past geological eras (Bianco, 1993), mainly in the last glaciation. The Italico-peninsular district in particular is characterized by the presence of a set of fish species with distribution range more or less wide, but that all overlap in Umbria having the river Tiber basin as its center of connection. The most representative species of this area are: Barbus tyberinus (Bonaparte, 1839), Padogobius nigricans (Canestrini, 1867), Rutilus rubilio (Bonaparte, 1837) and Squalius lucumonis (Bianco, 1982), an endemic species restricted to the Tuscany Latium district (Giannetto et al., 2013). Some of them are of particular conservational interest: Squalius lucumonis is listed as "species in critical risk of extinction" in red lists of the IUCN (Rondinini et al., 2013), while Padogobius nigricans and Barbus tyberinus are classified as "vulnerable species". One of the main conservation threats is represented by the introduction of exotic species that can cause extinction of endemic species and lead to a reduction of native biodiversity (Simberloff, 2010; Mejía-Mojica et al., 2015; Smith et al., 2015). Recent studies on aquatic ecosystems of the Mediterranean regions have demonstrated that the introduction of exotic species influence the functional composition of the fish communities (Marr et al., 2013). It is important in this context to investigate the mechanisms that determine the impact of exotic species on indigenous ones.

The main objectives of the present paper were to assess the presence and distribution of fish species in the river Tiber basin and to analyze the influence of alien species on the status of indigenous species. The same analysis were carried out in the past (Lorenzoni et al., 2006; Giannetto et al., 2012) and one of the purposes of this research was to evaluate the changes occurred over time.

The structure of the fish communities can be affected, as well as biotic factors such as the introduction of exotic species, also by abiotic factors such as temperature, depth, current rate (Smith et al., 2015). So another aim of the present study was to assess the environmental characterization and the role of abiotic factors in the distribution of fish species.

\section{MATERIALS AND METHODS}

The study area comprises the Umbrian portion of the river Tiber basin $\left(8412 \mathrm{~km}^{2}\right)$ (Figure 1); it includes many tributaries, the most important being the Nestore river (watershed $=1033 \mathrm{~km}^{2}$ ), 


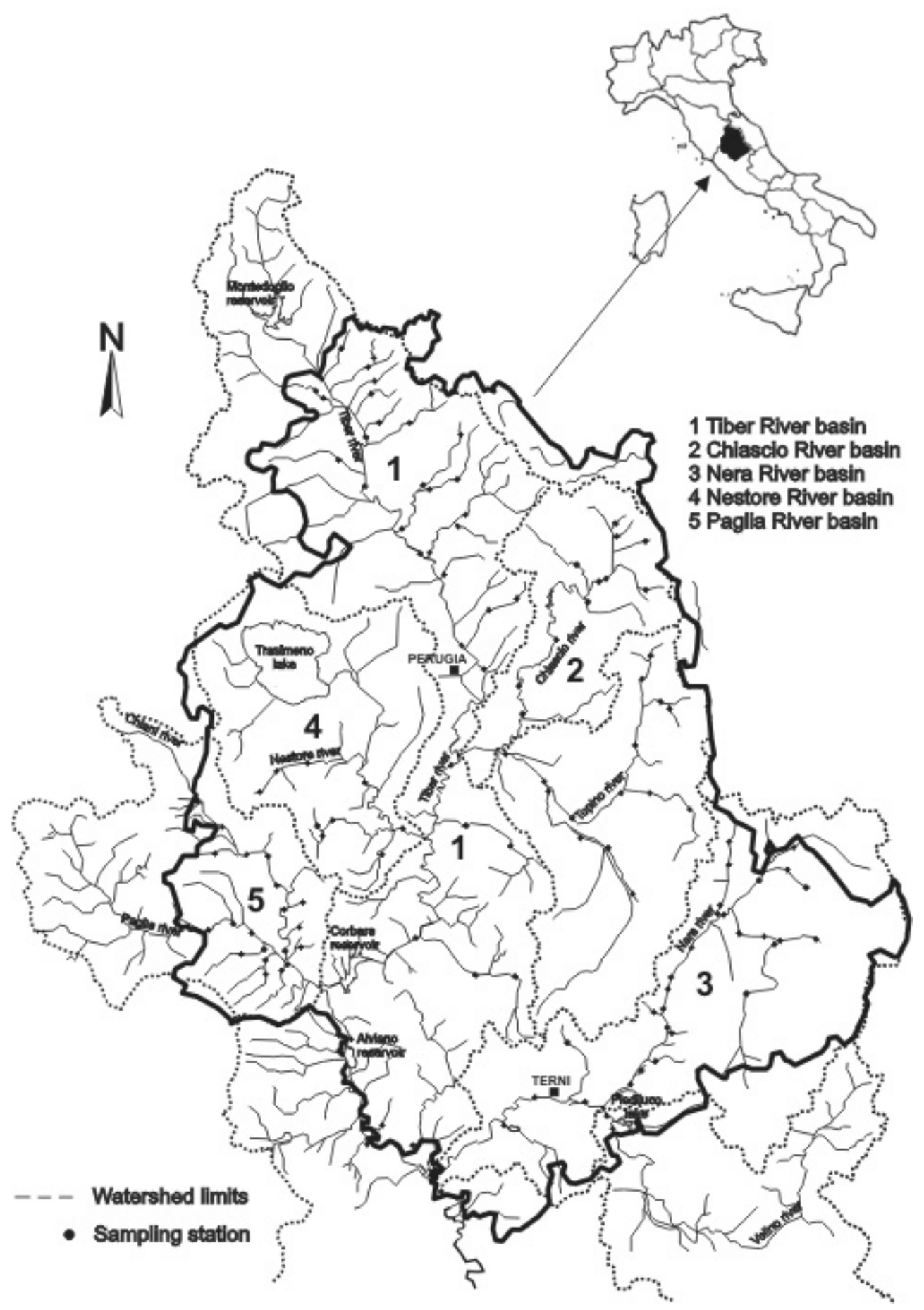

Figure 1

Study area and location of the sampling sites.

the Paglia river (1338 $\left.\mathrm{km}^{2}\right)$, the Chiascio river $\left(5963 \mathrm{~km}^{2}\right)$ and the Nera river $\left(4280 \mathrm{~km}^{2}\right)$. The study area was divided into five hydrographic units made up of the main sub-watersheds: the Chiascio, the Nera, the Nestore, the Paglia and the Tiber river's remainder which included the main channel and other minor tributaries. A total of 68 streams and rivers were included in the study area with 125 sampling stations. The analyses were carried out using the data of the Regional Fish Map of $1^{\text {st }}$ and $2^{\text {nd }}$ level and the $1^{\text {st }}$ update, respectively collected during the periods between the 1990-1996, 2000-2006 and 2007-2014. All the 125 sites were 
Table I

Environmental and biological parameters.

\begin{tabular}{|l|c|}
\hline \multicolumn{2}{|c|}{ Parameters } \\
\hline Altitude (m a.s.I.) & Water temperature $\left({ }^{\circ} \mathrm{C}\right)$ \\
Distance from the source $(\mathrm{km})$ & $\mathrm{pH}$ \\
Watershed area $\left(\mathrm{km}^{2}\right)$ & Conductivity $\left(\mu \mathrm{S} \cdot \mathrm{cm}^{-1}\right.$ at $\left.25{ }^{\circ} \mathrm{C}\right)$ \\
Average slope $(\%)$ & Dissolved oxygen $\left(\mathrm{O}_{2} \mathbf{m g} \cdot \mathrm{L}^{-1}\right)$ \\
Flow rate $\left(\mathrm{m}^{3} \mathrm{~s}^{-1}\right)$ & $\mathrm{N}-\mathrm{NH}_{3}\left(\mathrm{mg} \cdot \mathrm{L}^{-1}\right)$ \\
Wetted river section $\left(\mathrm{m}^{2}\right)$ & $\mathrm{SO}_{4}\left(\mathrm{mg} \cdot \mathrm{L}^{-1}\right)$ \\
Average current speed $\left(\mathrm{m} \cdot \mathrm{s}^{-1}\right)$ & $\mathrm{Cl}\left(\mathrm{mg} \cdot \mathrm{L}^{-1}\right)$ \\
E.B.I. & \\
\hline
\end{tabular}

sampled one time for each of the three census periods. The Regional Fish Map is a research promoted by the Umbria Region that relates to the census of fish species living in the catchment areas that have been investigated, the status of fish populations of greater interest and the environmental characterization of the analyzed rivers.

A census of the fish fauna was carried out at each sampling station. The fish were captured at low flow period using a continued or pulsed current electric shocker with power varying between 1500 and $4000 \mathrm{~W}$. All captured fishes were identified and counted. For all specimens, the total length $(\mathrm{TL})$ was measured to the nearest $0.1 \mathrm{~cm}$, and weight was measured to the nearest $0.1 \mathrm{~g}$ (Anderson and Neumann, 1996) and a sample of scales was collected from each specimen for age determination. For all reaches, tract length was defined as 10 times the wetted channel, with a minimum and maximum length of 50 to $400 \mathrm{~m}$. Some environmental and biological parameters were used to characterize the river sectors and these are reported in Table I. The Extended Biotic Index (EBI) (Ghetti, 1986) is a biotic index used to evaluate the overall water quality based on the composition of the macrobenthic fauna. This index is based on the sensitivity of key groups to pollution and on the number of component groups in a sample: clean streams are given an index of 15 and this value decreases as pollution increases. Hydraulic variables were measured at transects within each sampling reach; depth was measured at three or more points within each transect and velocity in three positions along the vertical of the same point of depth measurement. Watershed area, distance from the source, average slope and altitude were determined from IGM topographic maps. Field measurements of specific conductivity, $\mathrm{pH}$, water temperature and dissolved oxygen were made with electronic meters. The other chemical parameters of the water were determined according to APHA, AWWA and WPCF (1989) and APAT CNR IRSA (2003) specifications. The environmental variables were measured at the same time as fish sampling.

Some of the terms and definitions used are: introduced or exotic: any species voluntarily or accidentally released into an environment outside of its original range (Holcik, 1991; Cowx, 1997); introduced species are transplanted when they come from another country. Introduced species are translocated when they come from other italian watersheds (Delmastro, 1986). An introduced species is acclimatized when it breeds and naturally maintains itself without any human interference. The level of degradation in the fish fauna was evaluated using the Zoogeographic Integrity Coefficient (ZIC) (Bianco, 1990; Elvira, 1995) expressed as the ratio between the number of native fish species and the total number of species found. This index vary from one (no exotic present) to zero (maximum level of alteration).

As in 1996 the distinction between Barbus tiberynus and Barbus plebejus Bonaparte, 1839 had not been accepted by all authors (Zerunian, 2002), in the analyses all the Po barbels caught during the Regional Fish Map were considered as Tiber barbel, also in view of the fact that the presence of this species is limited to very few sampling stations located along the main channel of the river Tiber (Lorenzoni et al., 2010).

An analysis to verify the relationships among the environmental conditions of the investigated area was conducted using principal component analysis (PCA): the matrix used 15 variables (altitude, distance from the source, watershed area, average slope, flow rate, wetted river section, average speed of current, water temperature, $\mathrm{pH}$, specific conductivity, dissolved oxygen, ammonium, sulphates, chlorides and EBI) (Table I) and 375 observations. This analysis 


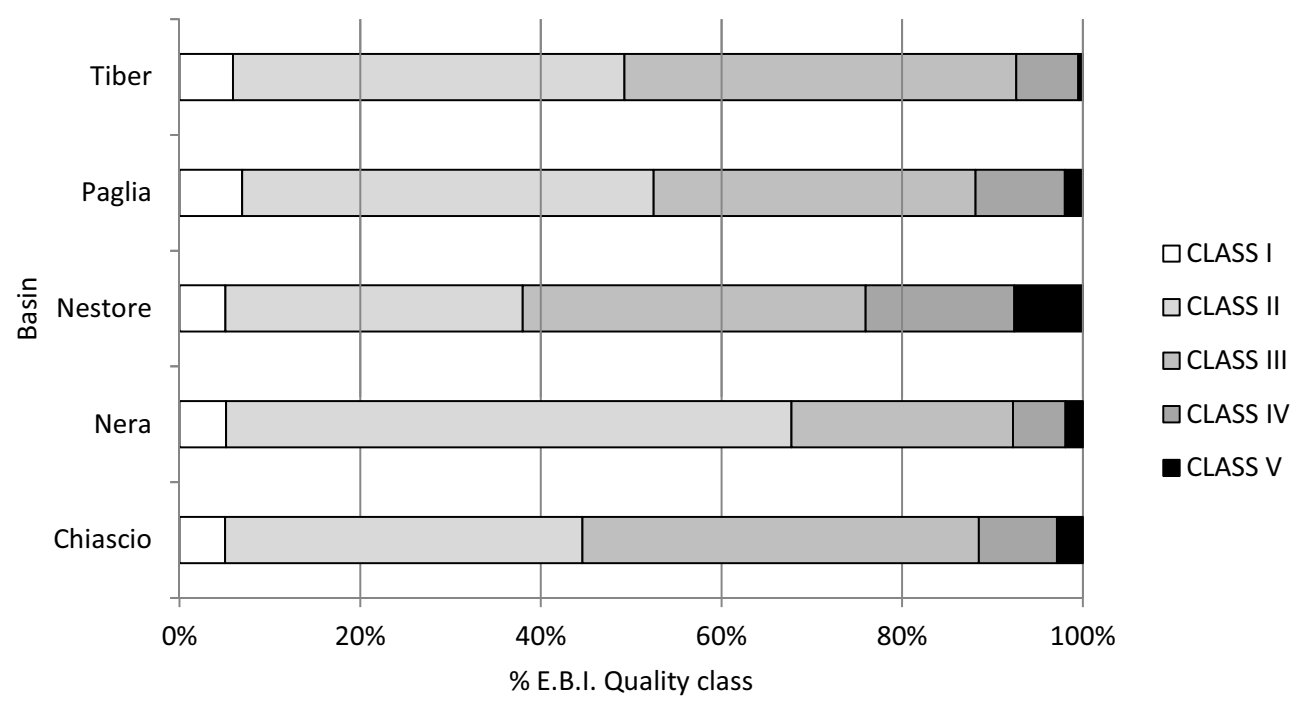

Figure 2

EBI Quality class: distribution of percentages among basins.

was performed with the STATISTICA 7 programs. All the variables $(N)$ were transformed $\left(\log _{10}\right.$ $(N+1))$ to normalize the distribution (Brown and Austen, 1996) and standardized to a mean of 0 and standard deviation of 1 . The existing relationship between the first axis of PCA with ZIC was subsequently investigated by regression analysis. The ZIC values were converted using the arcsine transformation.

To analyze the relationships among environmental and biological data matrices was used the Canonical Correspondence Analysis (CCA) (ter Braak, 1986), a multivariate direct gradient analysis method. The CCA analysis was processed with the CANOCO statistical package for Windows 4.5. The results of CCA generate a diagram that displays approximate values of the weighted averages fish assemblage parameters (points) with respect to the supplied environmental variables. In the diagram, the environmental variables are represented by arrows that roughly point in the direction of maximum factor variation (ter Braak, 1986). The length of the arrow is proportional to the rate of change; therefore, a long arrow indicates a large change and that change is strongly correlated with the ordination axes. The position of the points in relationship to the arrows indicates the relationship between each point and the variable represented by the arrow. Those that are farthest along towards the head of the arrow are those with the largest values for that variable. To assess the statistical significance of the ordination axis we run Monte Carlo tests for 1000 permutations. An axis was considered statistically significant if the eigenvalue from the randomly permuted set exceeded the original in 50 or fewer cases $\alpha=0.05$. The environmental matrix used included 15 variables and 375 observations (sampling stations). The fish assemblage matrix used included 39 variables (fish species) and 375 observations (sampling stations). The abundance of a fish species was coded using a scale that varies from 0 to 3 based on the population's density $\left(0 \mathrm{ind} / \mathrm{m}^{2}=\right.$ absent; $<0.05$ ind $\cdot \mathrm{m}^{-2}=$ rare; from 0.05 to $0.1 \mathrm{ind} \cdot \mathrm{m}^{-2}=$ sub-dominant; $>0.1 \mathrm{ind} \cdot \mathrm{m}^{-2}=$ dominant).

\section{RESULTS}

\section{> ENVIRONMENTAL AND BIOLOGICAL PARAMETERS}

The EBI values show that the water quality is very high, with the presence of many areas assigned to the first and second quality class, concerning areas with low human population, such as the Nera river basin; the worst situation refers to the areas of high incidence of human activities, such as the Nestore river basin (Figure 2). The distribution of EBI classes varied among the five basins $\left(\chi^{2}\right.$ Pearson $\left.=43.325 ; p=0.001\right)$. Compared to $1990-1996$, 


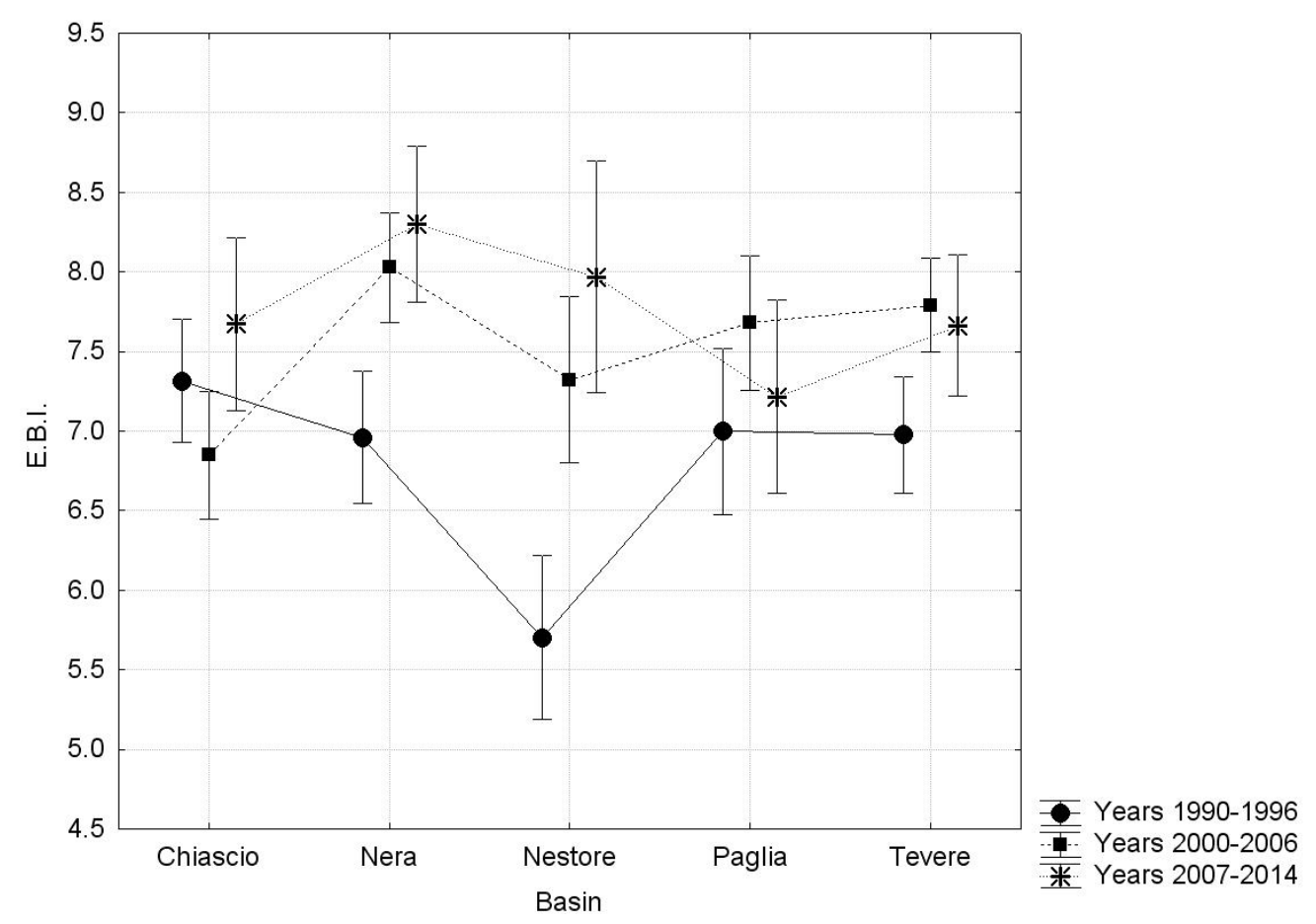

Figure 3

Distribution of average EBI values among basins in different periods. Vertical bars representing the 95\% confident level.

\section{Table II}

Principal component analysis: summary statistics. In bold values for $p<0.05$.

\begin{tabular}{|c|c|c|}
\hline & Factor 1 & Factor 2 \\
\hline Distance from the source (km) & -0.788997 & -0.343403 \\
\hline Watershed area $\left(\mathrm{km}^{2}\right)$ & -0.773475 & -0.433708 \\
\hline Altitude (m a.s.l.) & 0.643620 & -0.285560 \\
\hline Average slope (\%) & 0.495417 & 0.158143 \\
\hline pH & 0.179130 & -0.020271 \\
\hline Conductivity $\left(\mu \mathrm{S} \cdot \mathrm{cm}^{-1}\right.$ at $25^{\circ}$ & -0.519333 & 0.705725 \\
\hline $\mathrm{NNH}_{3}\left(\mathrm{mg} \cdot \mathrm{L}^{-1}\right)$ & -0.365013 & 0.354319 \\
\hline $\mathrm{SO}_{4}\left(\mathrm{mg} \cdot \mathrm{L}^{-1}\right)$ & -0.593694 & 0.495176 \\
\hline $\mathrm{Cl}\left(\mathrm{mg} \cdot \mathrm{L}^{-1}\right)$ & -0.450674 & 0.719955 \\
\hline Water temperature $\left({ }^{\circ} \mathrm{C}\right)$ & -0.178423 & -0.000444 \\
\hline $\mathrm{O}_{2}\left(\mathrm{mg} \cdot \mathrm{L}^{-1}\right)$ & 0.247196 & -0.229108 \\
\hline E.B.I. & 0.486878 & -0.330798 \\
\hline Average current speed $\left(\mathrm{m} \cdot \mathrm{s}^{-1}\right)$ & -0.167118 & -0.617775 \\
\hline Flow rate $\left(\mathrm{m}^{3} \cdot \mathrm{s}^{-1}\right)$ & -0.663165 & -0.581919 \\
\hline Wetted river section $\left(\mathrm{m}^{2}\right)$ & -0.749459 & -0.460893 \\
\hline
\end{tabular}

the environmental situation seems to have improved, especially in the case of the Chiascio, the Nera and the Nestore basins, while the situation is worsened over time in the Tiber river basin and in the Paglia river basin. The differences between the mean values among basins $(F=3.87 ; p=0.004)$, among periods $(F=22.16 ; p=0.001)$ and the crossing effect between the two categorical variables $(F=4.43 ; p=0.001)$ are statistically significant to the two-way factorial analysis of variance (Figure 3 ).

The results of the principal components analysis on environmental parameters and EBI are reported in Tables II and III. The first factor, that explains $28.20 \%$ of the overall variability, shows the changes that occur along the upstream-downstream gradient of a water course: to the decrease of altitude and the increase of the distance of the source, there is an increase 
Table III

Eigenvalues for factors 1-2 expressed as \% of total variance.

\begin{tabular}{|l|c|c|c|c|}
\cline { 2 - 5 } \multicolumn{1}{c|}{} & Eigenvalue & \% of total variance & Cum. eigenvalue & Cum. \% \\
\hline Factor 1 & 4.230 & 28.203 & 4.230 & 28.203 \\
Factor 2 & 2.895 & 19.298 & 7.125 & 47.501 \\
\hline
\end{tabular}

of the watershed area and of the wetted river section. In the Tiber river basin this gradient is associated with a progressive decline in water quality, clearly shown by the decrease of $\mathrm{EBI}$ and increased conductivity and concentration of dissolved salts, such as the sulphates. The downstream reaches, where the impact of human activities is high, show a more serious pollution. The second factor, that explains $19.30 \%$ of the overall variability, indirectly shows the link between two hydraulic variables, such as current speed and flow rate, and the conductivity and the chlorides: the dilution of pollutants increases along the longitudinal gradient of a river.

\section{> FISH FAUNA}

A list of the species found is reported along with information about their origin (Table IV). Barbus plebejus was considered indigenous because not all authors agree to consider it as an exotic species (Bianco, 1995; Zerunian, 2002). The brown trout was considered native or transplanted because some studies have shown the presence of many indigenous populations in the study area but also the presence of populations with a degree of introgressive hybridization more or less high. The same considerations can be applied for the pike. 40 species of fish were found. Only 14 are native. Of the remaining 26 alien species, 9 come from other italian basins, while 17 were transplanted from foreign basins. With respect to the results obtained in the Fish Map of 1st level, after a decade we can observe the emergence of 6 new alien species, of which 4 belong to the Cyprinidae family: Barbus barbus (Linnaeus, 1758), Gobio gobio (Linnaeus, 1758), Rhodeus sericeus (Pallas, 1776), Rutilus rutilus (Linnaeus, 1758); 1 to the Salmonidae family: Thymallus thymallus (Linnaeus, 1758); 1 to the siluridi family: Silurus glanis Linnaeus 1758. In the course of the 1st update 4 more exotic species were found: Blicca bjoerkna (Linnaeus, 1758), Ctenopharyngodon idellus (Valenciennes, 1844), Luciobarbus graellsii (Steindachner, 1866) (Buonerba et al., 2013), Salvelinus fontinalis (Mitchill, 1814). The percentages of higher occurrence relate to native species: Rutilus rubilio $(59.18 \%)$, Barbus tyberinus (58.19\%), Squalius squalus (Bonaparte, 1837) (58.62\%), Telestes muticelIus (Bonaparte, 1837) (46.89\%), Salmo trutta complex Linnaeus, 1758 (47.88\%), Padogobius nigricans (39.12\%) and Squalius lucumonis (35.31\%). Among the exotic species higher frequency values relate to Alburnus arborella (Bonaparte, 1841) (30.65\%), Carassius auratus (Linnaeus, 1758) (21.75\%), Protochondrostoma genei (Bonaparte, 1839) (25.71\%), and Cyprinus carpio (Linnaeus, 1758) (19.77\%).

There is a progressive increase over time of the number of exotic species for sampling station (Figure 4). Comparing the Fishing Maps of $1^{\text {st }}$ and $2^{\text {nd }}$ level an increase in the number of native species is observed, while it can observed an opposite pattern comparing the $2^{\text {nd }}$ level with the $1^{\text {st }}$ update (Figure 5). The differences between the three periods were highly statistically significant at Fisher's LSD Post Hoc test for the number of exotic species $(p=0.001)$. The differences between the years 1990-1996 and 2000-2006 of number of native species were not statistically significant at Fisher's LSD Post Hoc test $(p=0.096)$, while the differences between the years 2000-2006 and 2007-2014 where highly statistically significant at Fisher's LSD Post Hoc test $(p=0.002)$.

The relationship between the first PCA axis and the $\mathrm{ZIC}$ is described by a first order equation for each of the three different periods considered: $y=1.220+0.123 x\left(r^{2}=0.39, p=0.001\right)$ (1990-1996); $y=1.171+0.144 x\left(r^{2}=0.32, p=0.000\right)(2000-2006) ; y=1.169+0.116 x$ $\left(r^{2}=0.24, p=0.001\right)(2007-2014)$. In all cases there is a gradual decrease in ZIC proceeding from upstream to downstream. To eliminate the effect of the longitudinal gradient the comparison of the ZIC values among the three periods was performed by ANCOVA; this analysis 


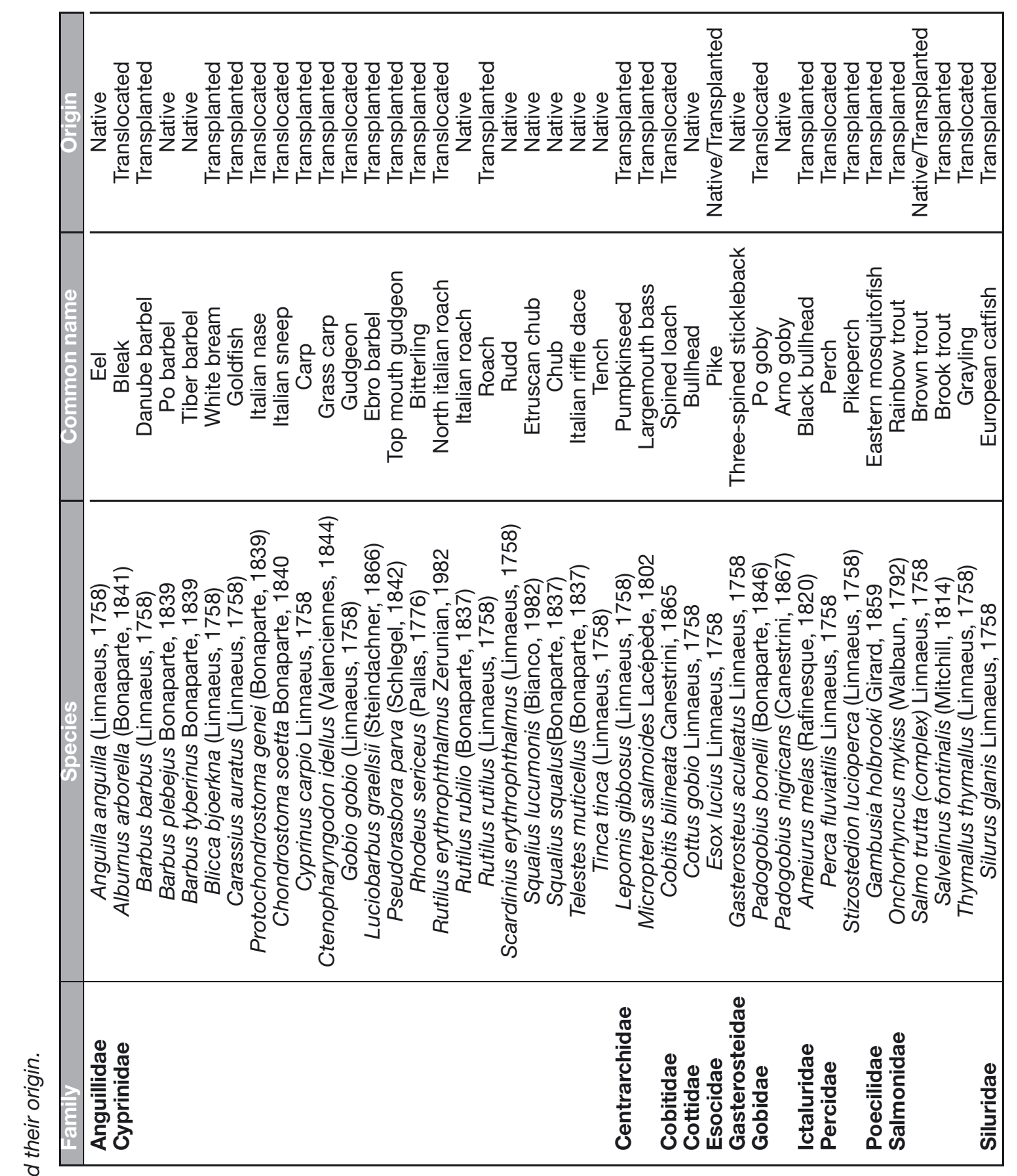




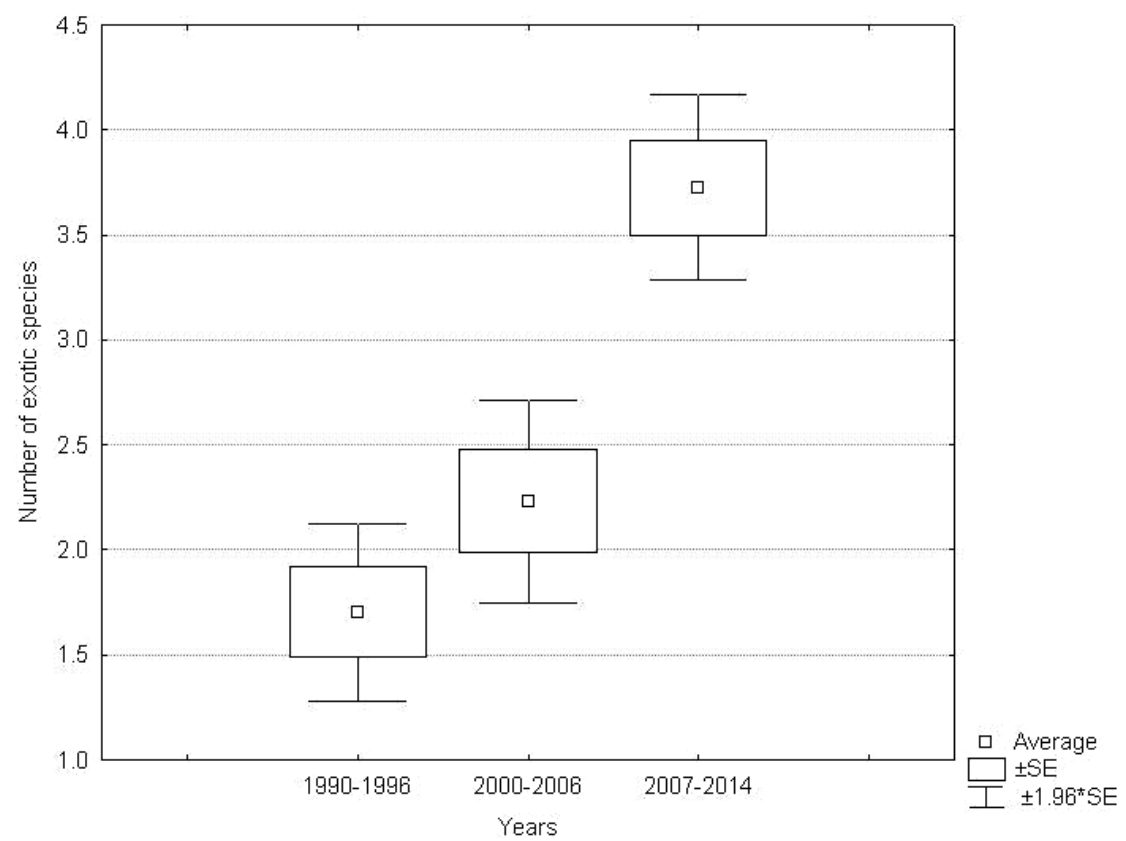

\section{Figure 4}

Trends over time of the number of exotic species.

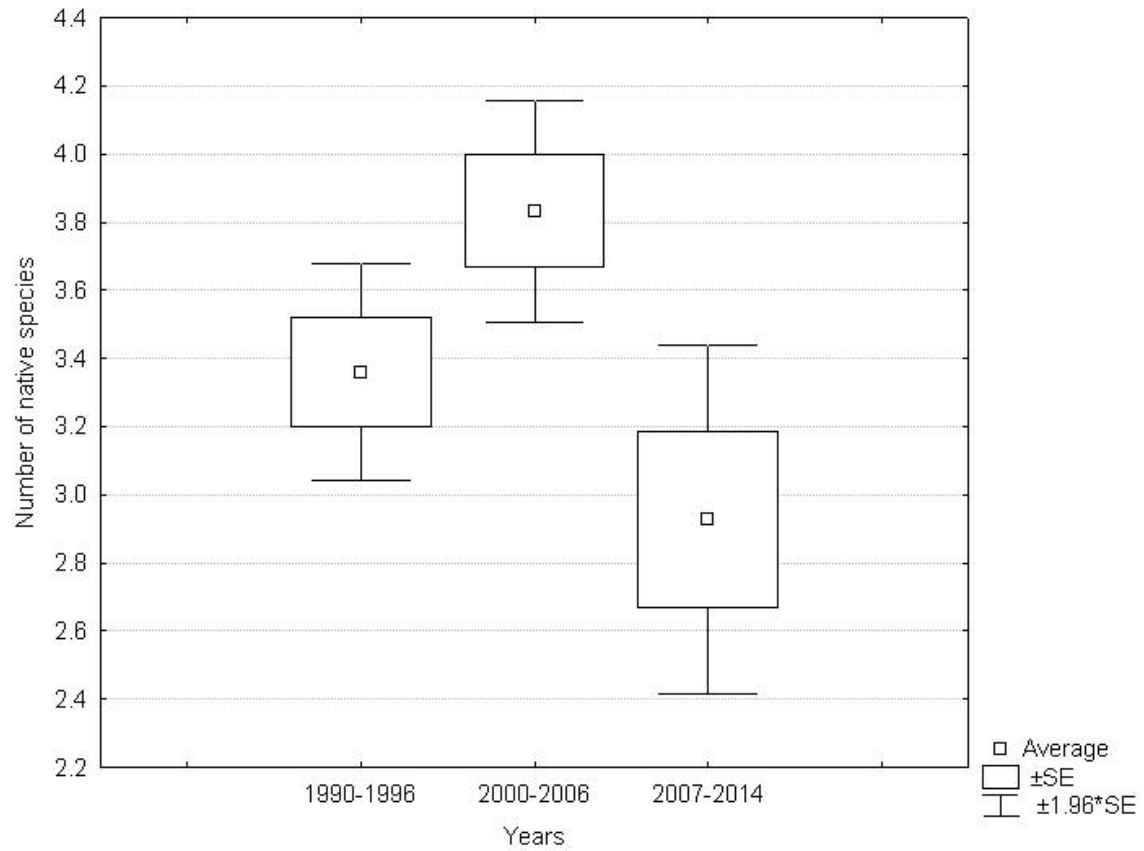

Figure 5

Trends over time of the number of native species.

was carried out using the first PCA axis as covariate, constant over time and equal to 0 , and using the periods as categorical variable. Figure 6 shows that there is a progressive decrease of the ZIC over time ( $F=2.37 ; p=0.032)$, much more marked over the first two periods. Upper stream reaches have fish communities composed of indigenous species. Stream reaches that have community with a low degree of integrity, are located on the lower part of the river and show a link between water quality and status of the communities. The ZIC is higher in the mountain reaches, characteristic of small and medium sized water courses, with fish community composed of species of the trout zone and of the rheophilic cyprinidae zone. 


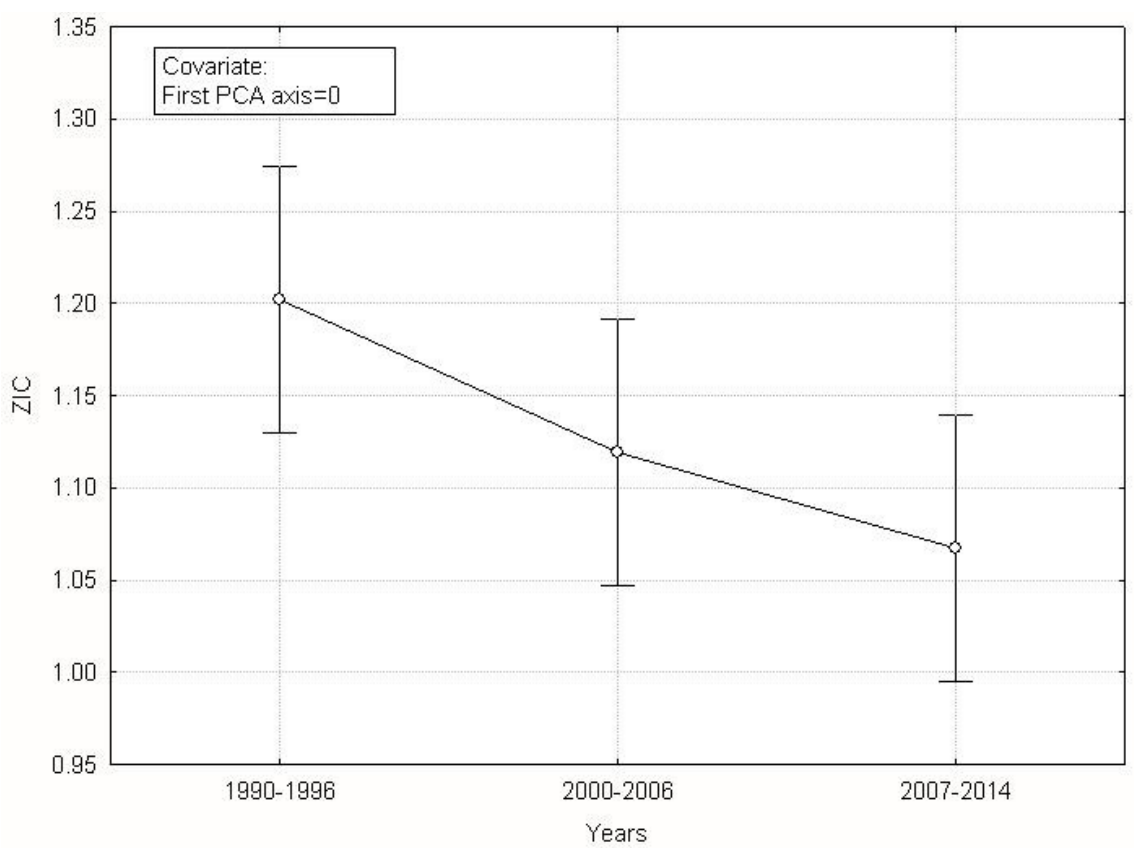

Figure 6

Trends over time of the ZIC values. Vertical bars representing the 95\% confident level.

Tables $\mathrm{V}$ and $\mathrm{VI}$ shows the results of the CCA analysis: the first 2 axis explain $72.10 \%$ of the total variability (significance: $p=0.001$ ); this result shows the close association between environmental variables and composition of the fish community. In Figures 7-8 are separately reported the plots of environmental variables and fish species. The first axis explains $55.10 \%$ of the overall variability (total inertia $=3.06$ ). According with the results of the PCA analysis, the CCA analysis describes the changes of the environmental characteristics that occurs along the upstream-downstream gradient. To the decrease of altitude and average slope there is an increase in the distance from the source, the watershed area, wetted river section and flow rate. The second axis is less informative (22.10\% of the overall variability) and reflects the progressive decline in the water quality along the upstream-downstream gradient: an inverse correlation between flow rate, watershed area and EBI, dissolved oxygen and chlorides can be observed. Also the position of fish species in the plot is strongly influenced by longitudinal gradient. The more distinctly rheofilic species, i.e. Salmo trutta and Cottus gobio Linnaeus, 1758 are positioned in the mountain portion of the investigated area; these are replaced, proceeding down the river, by an association of Onchorhyncus mykiss (Walbaum, 1792), Padogobius nigricans, Padogobius bonelli (Bonaparte, 1846), Squalius lucumonis and Rutilus rubilio, that characterizes the intermediate course of the analyzed rivers. In the central portion of the distribution prevail the rheofilic cyprinids and other fish species that characterize the barbel zone. At the left end of the distribution are positioned the most limnophilous fish species, typical of the downstream reaches (carp zone): Rutilus rubilio, Carassius auratus, Scardinius erythrophthalmus (Linnaeus, 1758), Micropterus salmoides Lacépède, 1802; many exotic species of recent introduction, such as Pseudorasbora parva (Schlegel, 1842), Silurus glanis and Rutilus rutilus also belong to this group.

\section{DISCUSSION}

In the study area the water quality is very high, with the presence of many areas assigned to the first and second EBI quality class, concerning areas with low human population, such as the Nera River basin. Compared to the past, the environmental situation seems to have improved, especially in the case of the Chiascio, the Nera and the Nestore basins. The situation 


\section{Table V}

Canonical and correlation coefficients of environmental variables with axis.

\begin{tabular}{|c|c|c|c|c|}
\hline & \multicolumn{2}{|c|}{ Canonical coefficients } & \multicolumn{2}{|c|}{ Correlations with axis } \\
\hline Environmental and biological parameters & $\overline{\mathrm{AX} 1}$ & $\overline{A X 2}$ & $\overline{\mathrm{AX1}}$ & $\overline{A X 2}$ \\
\hline Distance from the source $(\mathrm{km})$ & -0.176 & 0.022 & -0.451 & 0.306 \\
\hline Watershed area $\left(\mathrm{km}^{2}\right)$ & -0.156 & 0.534 & -0.395 & 0.360 \\
\hline Altitude (m a.s.l.) & 0.312 & -0.201 & 0.508 & -0.111 \\
\hline Average slope (\%) & -0.009 & -0.108 & 0.181 & -0.106 \\
\hline $\mathrm{pH}$ & 0.272 & 0.338 & -0.006 & 0.047 \\
\hline Conductivity $\left(\mu \mathrm{S} \cdot \mathrm{cm}^{-1}\right.$ at $\left.25^{\circ} \mathrm{C}\right)$ & -0.100 & 0.007 & -0.301 & -0.039 \\
\hline $\mathrm{NNH}_{3}\left(\mathrm{mg} \cdot \mathrm{L}^{-1}\right)$ & -0.049 & 0.187 & -0.205 & 0.084 \\
\hline $\mathrm{SO}_{4}\left(\mathrm{mg} \cdot \mathrm{L}^{-1}\right)$ & -0.225 & 0.001 & -0.445 & -0.036 \\
\hline $\mathrm{Cl}\left(\mathrm{mg} \cdot \mathrm{L}^{-1}\right)$ & -0.333 & -0.594 & -0.492 & -0.219 \\
\hline Water temperature $\left({ }^{\circ} \mathrm{C}\right)$ & -0.023 & 0.046 & -0.050 & 0.029 \\
\hline Dissolved oxygen $\left(\mathbf{m g} \cdot \mathrm{L}^{-1}\right)$ & 0.197 & -0.070 & 0.156 & -0.048 \\
\hline E.B.I. & 0.004 & -0.221 & 0.205 & -0.120 \\
\hline Average current speed $\left(\mathrm{m} \cdot \mathrm{s}^{-1}\right)$ & 0.183 & 0.038 & 0.232 & 0.226 \\
\hline Flow rate $\left(m^{3} \cdot s^{-1}\right)$ & -0.008 & 0.107 & -0.090 & 0.316 \\
\hline Wetted river section $\left(\mathrm{m}^{2}\right)$ & -0.174 & -0.062 & -0.180 & 0.245 \\
\hline
\end{tabular}

\section{Table VI}

Eigenvalues of axis 1 and 2 expressed as \% of total variance.

\begin{tabular}{|l|c|c|}
\cline { 2 - 3 } \multicolumn{1}{c|}{} & Axis 1 & Axis 2 \\
\hline Eigenvalues & 0.342 & 0.137 \\
Species-environment correlations & 0.731 & 0.563 \\
Cumulative percentage variance & 55.100 & 77.200 \\
\hline
\end{tabular}

is worsened over time in the areas of high incidence of human activities, such as the case of the river Tiber and of the river Paglia basins. In that areas there is the problem of water pollution from domestic and industrial point sources and from agricultural activity; also the presence of numerous water catchment for irrigation purposes aggravated the environmental situation.

The fish fauna of river Tiber basin has changed in the last 25 years with the appearance of 10 new exotic species. With the exception of Salvelinus fontinalis, Thymallus thymallus, Ctenopharyngodon idellus and partially Onchorhyncus mykiss, the other new exotic species are established with self-sustaining populations. In most cases the introduction of exotic species was unintentional and it was probably consequent to fish restocking programs: often in the past were carried out stocking programs with juvenile cyprinid fishes among which there were exotic species difficult to distinguish from native ones.

At present the $65 \%$ of the species that have been counted in the investigated area are exotic. Six native rheofilic species were detected with a frequency greater than $30 \%$ (Squalius squalus, Squalius lucumonis, Barbus tyberinus, Rutilus rubilio, Padogobius nigricans, Telestes muticellus and Salmo trutta). Among the exotic species higher frequency values relate to those of oldest introduction: Alburnus arborella (30.65\%), Carassius auratus (21.75\%), Protochondrostoma genei (25.71\%), and Cyprinus carpio (19.77\%).

The introduction of invasive alien species on ecosystems can determine the reduction of the natural area of distribution of native species and the extinction of native species or decline in their populations (Simberloff, 2010; Mejìa-Mojica et al., 2015). In the river Tiber basin Barbus barbus (Linnaeus, 1758) is a threat to Barbus tyberinus because of competition and hybridization phenomena between the two species (Carosi et al., 2006). Also the introduction and the rapid expansion of Padogobius bonelli in the upper part of river Tiber basin is having a strong impact on Padogobius nigricans (Pompei et al., 2014). Among the most recently introduced species, Luciobarbus graellsii is the most concerning, because its presence 


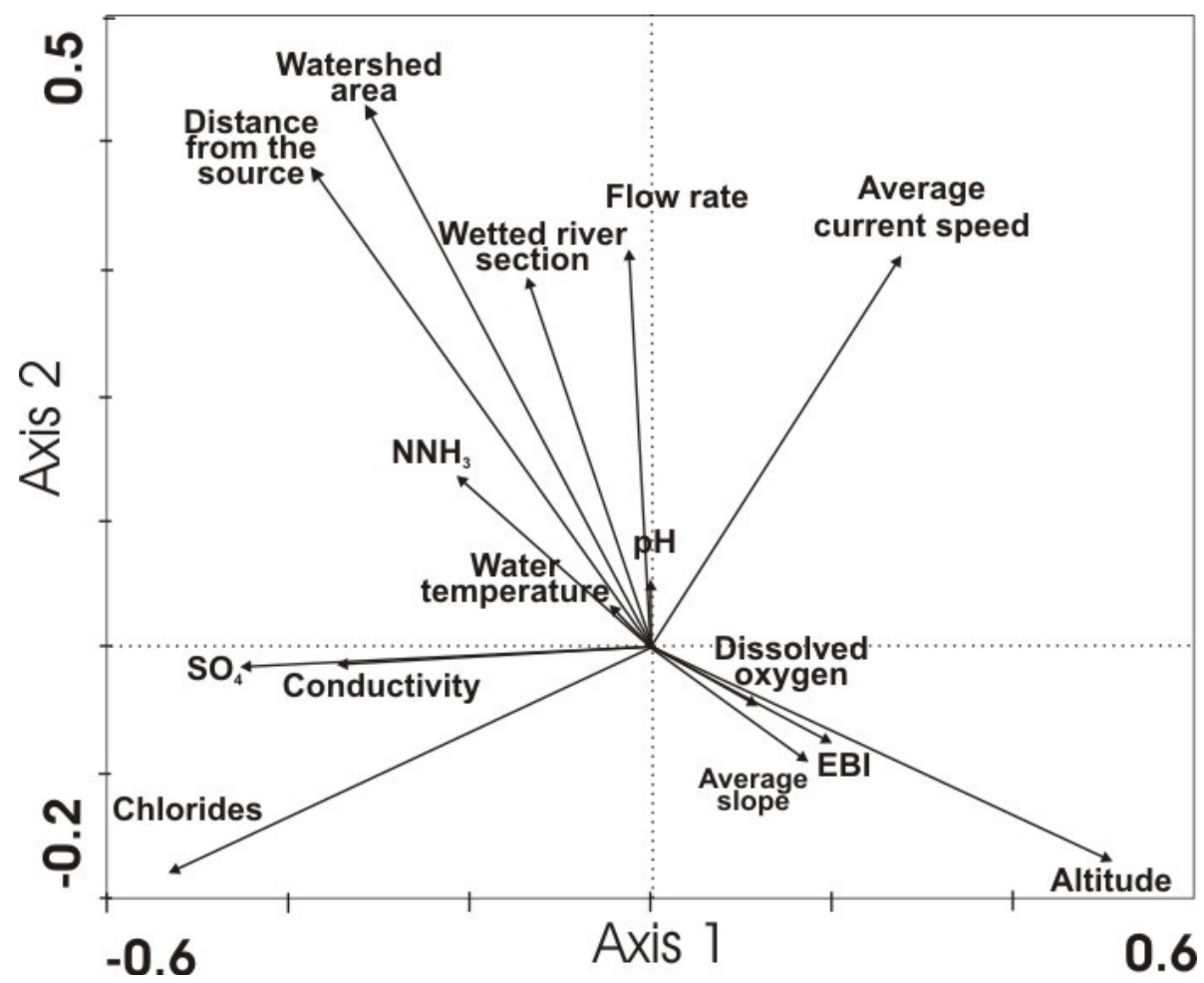

Figure 7

Canonical correspondence analysis (CCA): plot of environmental variables.

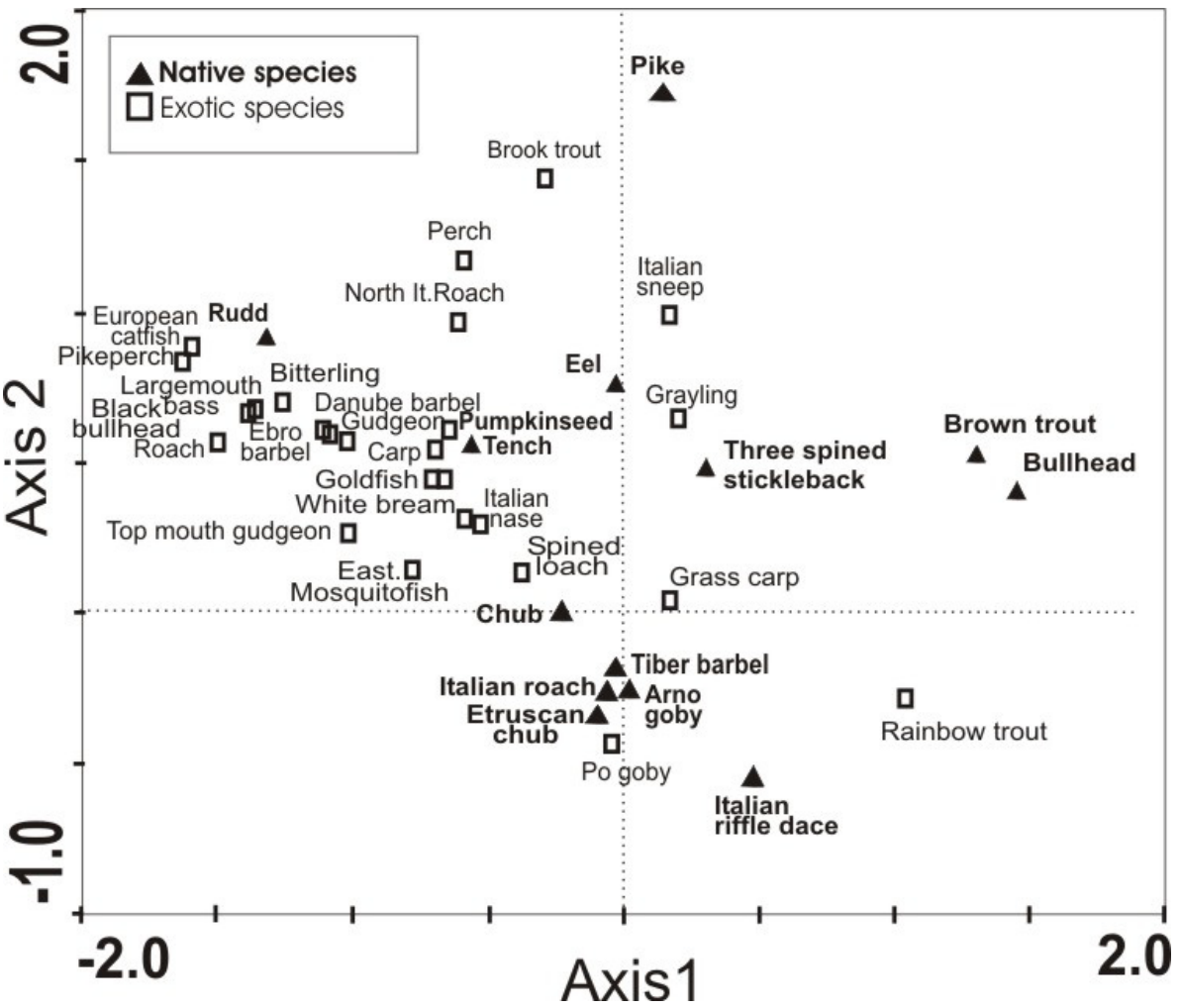

Figure 8

Canonical correspondence analysis (CCA): plot of fish species. 
has been detected in 2007 but it is already present in the river Tiber with an abundant and well-structured population (Buonerba et al., 2013). Recent studies based on the use of relative weight to test the impact of the presence of exotic species on the condition of endemic native species in the Tiber river basin (Giannetto et al., 2012), showed that Barbus tyberinus and Telestes muticellus represented the most sensitive species to the presence of non native species. Our results confirms the concern and show that there is a progressive increase over time of the medium number of exotic species for sampling station, while there is an opposite pattern for the ZIC index and for the number of native species, just for the last period.

Both PCA and CCA analyzes results show the changes of the environmental characteristics and the progressive decline in water quality that we can observe in the rivers of the study area along the upstream-downstream gradient. Fish assemblage composition varied along the rivers according to environmental variables (Godinho et al., 2000). Numerous studies about river fish communities showed that species richness and the importance of limnophilic species increase with river size, in according to the modifications of stream habitats along the longitudinal gradient (Belliard et al., 1997). In the river Tiber basin the assemblage of different fish species, proceeding from upstream to downstream, follows the zonation scheme adopted for the Umbria region (Mearelli et al., 1995). The brown trout is the only species present in many mountain rivers, while the rheophilic cyprinids community is composed of an association of Barbus tyberinus, Telestes muticellus, Squalius squalus, Squalius lucumonis, Rutilus rubilio and Padogobius nigricans. The situations of best integrity were found in mountain rivers of all the basins and in the Nera river basin upstream of Terni city (Lorenzoni et al., 2010). Very altered fish communities were found along the Tiber river (in the southern part of the basin) and in the upper and middle stream reaches of the rivers Nestore and Paglia. Upper stream reaches have species adapted to the cold waters and the fish community are dominated by salmonidae, intermediate reaches are characterized by the presence of native cyprinids, including many endemics, and downstream reaches are distinguished by the presence of many alien fishes adapted to warmer waters with low current rate (Marchetti and Moyle, 2001; Smith et al., 2015). For the river Tiber basin the CCA results confirm that the alteration degree of the fish communities is closely linked to the longitudinal gradient and this trend, already highlighted by previous research (Lorenzoni et al., 2006), it is confirmed in time. The ZIC is higher in the intermediate and high parts of rivers. Compared to the Fishing Map of 1 st level we have observed a decrease in total integrity situations. Alien species are more invasive in freshwaters already altered by human activities (Baltz et al., 1993; Moyle and Light, 1996; Dudgeon et al., 2006). Exotic fish are dominant in conditions of low environmental quality, while native species are less tolerant to the alteration of the aquatic ecosystems (Darwall, 2009; Mejía-Mojica, 2015). Many authors reported that native fishes are associated with high water quality, flowing water and structurally complex habitats (Marchetti and Moyle, 2001). As has been reported for some Mediterranean basins (Özdemir et al., 2015) also in the lower stream reaches of the investigated area the combined action of pollution and introduction of non-native species has resulted in a gradual decrease in the autochthonous component in fish communities. Increased occurrence of exotic species in lower stream reaches has also been reported in some rivers of Western North America (Smith et al., 2015). In the present study, in relation to situations in which there was an improvement in water quality, the reduction of the number of native species recorded in the last decade still seems to be more related to the impact of exotic species rather than pollution.

\section{CONCLUSIONS}

The introduction of exotic species represents a serious threat to fish biodiversity, because a few species due to their large ecological plasticity, become increasingly widely distributed, while the number of indigenous endemic species reduces. The information collected in the present study are the indispensable premise for taking the necessary strategies for conservation of endangered species. 
In the investigated area remain a substantial number of rivers that have not been irreversibly altered from their original state by human activities. In particular the small rivers of the Tiber river basin represent a refuge area for the indigenous fish community, which in many cases are still unchanged, and may play a key role in the maintenance of native biodiversity. In these cases, it is particularly important to establish large protected areas and to prevent the introduction of exotic species.

In some cases the presence of insurmountable natural and human made barriers preventing colonization of exotic species in the upper stream reaches and it is determinant in the conservation of native fishes; in these cases the application of the EC Water Framework Directive $(2000 / 60)$ to the European water bodies, with regard to the ecological continuity, should be graduated according to the preservation of endemic freshwater ichtyofauna.

Given the torrential regime of the analyzed rivers, the maintaining of Minimum Vital Flows (MVF), plays a decisive role (Bicchi et al., 2006), even considering that climate models predict future accentuations of drought phenomena as a result of global warming. Natural variability in flows and water levels is essential to underpin conservation strategies for freshwater biodiversity and their habitats (Dudgeon et al., 2006). The loss of flow that occurs in drought periods can determine isolation of fishes with different thermal tolerance (Mejía-Mojica et al., 2015).

The water pollution and the alteration of habitats have a decisive effect on the disappearance of the less tolerant species (Mejía-Mojica et al., 2015). Especially in the lower stream reaches, the recovery of the integrity quality of the fish communities is subordinate to the recovery of water quality and the containment of exotic species. The conservation of native fish biodiversity should be evaluated in concert with fishery management (Pascual et al., 2002). The angling web forums have proven particularly useful in the early detection of the introductions of exotic species, such as the case of Perca fluviatilis in continental Portugal (Banha et al., 2015).

A decisive role in the prevention of the introduction of exotic species is played by environmental education. It is important to spread information on the impact of the exotic species and information on the possible management tools (Genovesi, 2007).

\section{ACKNOWLEDGEMENTS}

We would like to thank the editorial board and the anonymous referee for their valuable comments that considerably improved the previous version of the article.

\section{REFERENCES}

Anderson R.O. and Neumann R.M., 1996. Length, weight and associated structural indices. In: Murphy B.R. and Willis D.W. (eds.), Fisheries techniques. American Fisheries Society, Bethesda, pp. 447-483.

APAT CNR IRSA, 2003. Metodi analitici per le acque. Manuali e linee guida 29.

APHA AWWA WPCF, 1989. Standard methods for the examination of water and waste water. American Public Health Association, Washington.

Baltz D.M. and Moyle P.B., 1993. Invasion resistance to introduced species by a native assemblage of California stream fishes. Ecol. Appl., 3, 246-255.

Banha F., Ilhéu M. and Anastácio P.M., 2015. Angling web forums as an additional tool for detection of new fish introductions: the first record of Perca fluviatilis in continental Portugal. Knowl. Manag. Aquat. Ecosyst., 416, 03.

Belliard J., Boët P. and Tales E., 1997. Regional and longitudinal patterns of fish community structure in the Seine River basin, France. Environ. Biol. Fishes, 50, 133-147.

Bianco P.G., 1990. Proposta di impiego di indici e coefficienti per la valutazione dello stato di degrado dell'ittiofauna autoctona delle acque dolci. Rivista di Idrobiologia, 29, 130-149. 
Bianco P.G., 1993. L'ittiofauna continentale dell'Appennino umbro-marchigiano, barriera semipermeabile allo scambio di componenti primarie tra gli opposti versanti dell'Italia Centrale. Biogeographia, 17, 427-485.

Bianco P.G., 1995. A revision of the Italian Barbus species (Cypriniformes: Cyprinidae). Ichtiol. Explor. Freshwater, 6, 305-324.

Bicchi A., Angeli V., Carosi A., Mearelli M., La Porta G., Spigonardi M.P., Viali P. and Lorenzoni M., 2006. Estimate of the Minimum Viable Flow in the river Paglia basin (Province of Terni, Central Italy). Quaderni ETP, 34, 117-126.

Buonerba L., Pompei L. and Lorenzoni M., 2013. First record of Iberian barbel Luciobarbus graellsii (Steindachner, 1866) in the Tiber River (Central Italy). Biolnvasions Records, 2, 297-301.

Carosi A., Pedicillo G., Bicchi A., Angeli V., Ghetti L. and Lorenzoni M., 2006. Distribuzione e abbondanza di Barbus barbus (Linnaeus, 1758) nel bacino del fiume Tevere in Umbria. Quaderni ETP, 34, 241-250.

Cowx I.G., 1997. L'introduction d'espèces de poissons dans les eaux douces européennes : succès économique ou désastre écologique ? Bull. Fr. Pêche Piscic., 344-345, 57-77.

Darwall W., Smith K., Allen D., Seddon M., McGregor Reid G., Clausnitzer V. and Kalkman V., 2009. Freshwater biodiversity a hidden resource under threat. In: Vié J., Hilton Taylor C. and Stuart S.N. (eds.), Wildlife in a changing world: an analysis of the 2008 IUCN Red List of Threatened species. IUCN, Gland, pp. 43-53.

Dudgeon D., Arthington A.H., Gessner M.O., Kawabata Z., Knowler D.J., Lévêque C., Naiman R.J., Prieur-Richard A.H., Soto D., Stiassny M.L.J. and Sullivan C.A., 2006. Freshwater biodiversity: importance, threats, status and conservation challenges. Biol. Rev., 81, 163-182.

Elvira B., 1995. Conservation status of endemic freshwater fish. Biol. Conserv., 72, 129-136.

Genovesi P., 2007. Towards a European strategy to halt biological invasions in inland waters. In: Biological invaders in inland waters: profiles, distribution and threats. Springer, pp. 627-637.

Ghetti P.F., 1986. I macroinvertebrati nell'analisi di qualità dei corsi d'acqua. Bertelli, Trento.

Giannetto D., Carosi A., Franchi E., Ghetti L., Pedicillo G., Pompei L. and Lorenzoni M., 2012. Assessing the impact of non-native freshwater fishes on native species using relative weight. Knowl. Manag. Aquat. Ecosyst., 404, 03.

Giannetto D., Carosi A., Ghetti L., Pedicillo G., Pompei L. and Lorenzoni M., 2013. Ecological traits of Squalius lucumonis (Actinopterygii, Cyprinidae) and main differences with those of Squalius squalus in the Tiber River Basin (Italy). Knowl. Manag. Aquat. Ecosyst., 409, 04.

Godinho F.N. and Ferreira M.T., 2000. Composition of endemic fish assemblages in relation to exotic species and river regulation in a temperate stream. Biol. Invasions, 2, 231-244.

Holcik J., 1991. Fish introduction in Europe with particular reference to its Central and Eastern part. Canadian J. Fish. Aquat. Sci., 48, 13-23.

Kottelat M. and Freyhof J., 2007. Handbook of European Freshwater Fishes. Kottelat.

Lorenzoni M., Mearelli M. and Ghetti L., 2006. Native and exotic fish species in the Tiber river watershed (Umbria - Italy) and their relationship to the longitudinal gradient. Bull. Fr. Pêche Piscic., 382, 19-44.

Lorenzoni M., Ghetti L., Carosi A. and Dolciami R., 2010. La fauna ittica e i corsi d'acqua dell'Umbria. Petruzzi Editore, Perugia.

Marchetti M.P. and Moyle P.B., 2001. Effects of flow regime on fish assemblages in a regulated California stream. Ecol. Appl., 11, 530-539.

Marr M.S., Olden J.D., Leprieur F., Arismendi I., Caleta M., Morgan D.L., Nocita A., Šanda R., Tarkan A.S. and García-Berthou E., 2013. A global assessment of freshwater fish introductions in mediterranean-climate regions. Hydrobiologia, 719, 317-329.

Mearelli M., Giovinazzo G., Lorenzoni M., Petesse M.L. and Carosi A., 1995. Zonazione ittica dei corsi d'acqua del bacino del fiume Tevere. SITE Atti, 16, 669-671.

Mejía-Mojica H., Contreras Mac-Beath T. and Ruiz-Campos G., 2015. Relationship between environmental and geographic factors and the distribution of exotic fishes in tributaries of the balsas river basin, Mexico Environ. Biol. Fish., 98, 611-621.

Moyle P.B. and Light T., 1996. Biological invasion of freshwater: empirical rules and assembly theory. Biol. Conserv., 78, 149-161. 
Özdemir N., Tarkna A.S., Agdamar S., Top N. and Karakus U., 2015. Ecological requirements and distribution of native and introduced freshwater fishes in a Mediterranean-type basin (Mugla, Sw Turkey) Fresenius. Environ. Bull., 24, 3-13.

Pascual M., Macchi P., Urbanski J., Marcos F., Rossi C.R., Novara M. and Dell'Arciprete P., 2002. Evaluating potential effects of exotic freshwater fish from incomplete species presence-absence data. Biol. Invasions, 4, 101-113.

Pompei L., Giannetto D. and Lorenzoni M., 2014. Feeding ecology of Padogobius nigricans (Canestrini, 1987) and Padogobius Bonelli (Bonaparte, 1846) in Aggia River (Umbria, Italy) and their diet overlap. Hydrobiologia, 740, 1, 101-113.

Rondinini C., Battistoni A., Peronace V. and Teofili C. (Compilers), 2013. Lista Rossa IUCN dei Vertebrati Italiani. Comitato Italiano IUCN e Ministero dell'Ambiente e del Mare, Roma, Italia, $54 \mathrm{p}$.

Simberloff D., 2010. Invasive species. In: Sodhi N.S. and Ehrlich P.R. (eds.), Conservation biology for all. Oxford University, Oxford, pp. 131-152.

Smith C.D., Quist M.C. and Hardy R.S., 2015. Fish assemblage structure and habitat associations in a large western river system. River Res. Appl., DOI: 10.1002/rra.2877.

Smith K.G. and Darwall W.R.T. (Compilers), 2006. The Status and Distribution of Freshwater Fish Endemic to the Mediterranean Basin. IUCN, Gland, Switzerland and Cambridge, UK, 34 p.

ter Braak C.J.F., 1986. Canonical correspondence analysis: a new eigenvector technique for multivariate direct gradient analysis. Ecology, 67, 1167-1179.

Zerunian S., 2002. Condannati all'estinzione? Edagricole, Bologna, $220 \mathrm{p}$

Cite this article as: A. Carosi, L. Ghetti, A. Forconi and M. Lorenzoni, 2015. Fish community of the river Tiber basin (Umbria-Italy): temporal changes and possible threats to native biodiversity. Knowl. Manag. Aquat. Ecosyst., 416, 22. 